\title{
Artigo
}

\section{Regional integration as "second-best" alternative in post-financial crisis world: lessons from the European Monetary Union to the Mercosur and Unasur}

Integração regional como "segunda-melhor" alternativa no mundo pós-crise financeira: liçóes da União Monetária Europeia para o Mercosul e Unasul

Renato Saraiva ${ }^{3}$

Thaís Dutra Fernández ${ }^{4}$

DOI: $10.5752 / P .1809-6182.2018 \mathrm{v} 15 . \mathrm{n} 2 . \mathrm{p61}$

Recebido em: 07 de agosto de 2018 Aceito em: 11 de dezembro de 2018

\begin{abstract}
The International Monetary System does not reflect transformations in the global economy. Being impossible to reform it, economic integration processes may be a "second-best" alternative. By analyzing the European Monetary Union we conclude that MERCOSUR and UNASUR should conceive regimes in less restrictive forms and develop fiscal and political integration.
\end{abstract}

Keywords: Regional Integration; European Monetary Union; South America integration blocks.

\section{Resumo}

O Sistema Monetário Internacional não reflete as transformaçôes da economia global. Sendo impossivel reformá-lo, os processos de integração econômica podem ser uma "segunda melhor" opção. Analisando a União Monetária Europeia, conclui-se que o MERCOSUL e UNASUL deveriam conceber formas menos restritivas de integração e desenvolver a integração fiscal e política.

Palavras-chave: Integração Regional; União Monetária Europeia; Blocos de integração da América do Sul.

\footnotetext{
3. Master's Candidate in Strategic International Studies and Bachelor in International Relations at Universidade Federal do Rio Grande do Sul. http://lattes.cnpq.br/1724953395733728 . ORCID: 0000-0002-6298-6296.

4. Master's Student in Human Rights and Humanitarian Action at Institut d'études politiques de Paris (SciencesPo) and Master's Candidate in International Strategic Studies at Universidade Federal do Rio Grande do Sul. Bachelor in Law at the Universidade Federal de Minas Gerais and in International Relations at Pontifícia Universidade Católica de Minas Gerais. http://lattes.cnpq.br/1749704251417271. ORCID: 0000-0002-2836-2287
} 


\section{Introduction}

After the Second World War, the International Monetary System (IMS), as we currently know started to develop, aiming at recovering the economy of European states, which was devastated after years of armed conflicts. Although today the IMS institutions - the International Monetary Fund (IMF) and the World Bank - are universal, their structure remains barely unchanged since their establishment, being replicated in other financial institutions created later.

Through cooperative performance of the Group of Twenty (G20), developing countries were able to play a more active role during the 2008 Crisis, which also prompted discussions of reforms in IMF Governance. However, conservative discourse has returned to the spotlight since the crisis began to ease, in a way that developed states gave up the possibility of reforming the IMS.

In this context of stagnation, economic integration presents itself as an alternative to states. Those participating in integration structured can shape them according to their own interests and intentions. In the past years, there has been significant increase in regional agreements, which proves the importance and the relevance of this form of integration.

In this paper, we aim to analyze the outcomes produced by the European Monetary Union to obtain lessons for two South American integration blocks: Union of South American Nations (UNASUR) and Southern Common Market (MERCOSUR). Our main argument is that regional integration is a second best alternative from unilateral openness in an unreformed International Monetary System. However, We conclude that it is necessary to conceive regimes of monetary cooperation in less restrictive forms than a monetary union, maintaining the autonomy of the economic policies, and developing forms of fiscal and political integration, through common social policies.

In order to reach this conclusion, this paper is divided in three sections. In the first one, we discuss the importance of processes of economic integration as an alternative to an unstable and unreformed international monetary system in the post-financial crisis world. Secondly, we briefly analyze the European Monetary Union experience. And, thirdly, having this as a reference, we discuss the monetary cooperation and the integration processes of UNASUR and MERCOSUR.

\section{Economic Integration as the Second-Best Alternative}

The Theory of Second-Best arises from the orthodox perspective of economics, according to which integration processes could convey an advantage, because they can lead to greater trade openness among partners, even if they are still far from an optimal situation of absolute free trade. Therefore, economic integration can be considered a "Second-Best" option if compared to the first option of widespread commercial freedom (BAUMANN; CANUTO; GONÇALVES, 2004, p. 110).

Nevertheless, besides its original orthodox meaning, integration is also a "Second-Best" option given the uncertainties of the International Monetary System. The end of the Bretton Woods System gave place to a period defined by the multiplicity of exchange rate regimes, both in transaction currencies and in adjustment criteria, in which major international currencies floated freely. Two main characteristics of this period were the absence of a prior fixation of values (the exchange-rate system was not fixed) and the elimination of several instruments of control and regulation of the financial system. There- 
fore, there was more properly, a "non-system". The 1990s witnessed a series of financial and foreign exchange crises due to the volatility of external resource flows and due to the contagion effect. All of this brought to the forefront debates about a new international financial architecture and of a need to reform existing mechanisms and institutions (BAUMANN; CANUTO; GONÇALVES, 2004, p. 404-409).

Such debates arose during the subprime crisis of 2008. The G20 proved to be the most effective mechanism of international economic governance to respond to it. During both times - the financial crisis of the 1990s and of 2008 - institutions that gathered only developed countries, such as the Group of Eight (G8), proved to be insufficient and unable to provide solutions on their own. The inability of systems that prevailed during Cold War was clear, since their decisions were top-down and did not consider the Global South. Developing countries could no longer be left out of decision-making processes and needed to be included in decision-making processes. According to Carvalho (2012), the G20 arose in the context of insufficient leadership from developed countries to coordinate a response to the 2008 crisis, and of distrust about the efficiency of the IMF and of the United Nations (UN) to discuss and determine effective solutions, due to their large numbers of members.

The financial crisis of 2008 was in reality a crisis of the financial globalization process, in the sense that was a consequence of the tendency of creating a "single global financial market" by the desregulamentation in national markets and the liberalization in capital fluxes. If the macroeconomic response to the crisis prevented a new 1930's depression, it did not created a solid and stable environment. And, as the post-financial crisis world still suffers with fragile economic growth, emerging economies are the most exposed to financial instabilities. Due to the hierarchical and asymmetrical structure of the international monetary and financial system, emerging countries are more vulnerable to volatile flows of capital and contagion effects (AKB, 2011).

There has not been a breach with traditional institutions from Bretton Woods, such as the IMF and the World Bank. There was no attempt to quit or to replace those institutions, but rather an attempt to include them, since their presidents took part in G20 meetings and discussions. This does not mean a mere acceptance of these institutions by emerging countries, which sought structural reforms to increase their participation. All members must accept the decisions taken in these fora; therefore, increasing the number and diversity of participants would also increase their legitimacy. When guidelines are negotiated and agreed upon also by developing countries, they are more likely to be accepted and observed.

While efforts by the G20 have proven to be crucial for resolving the Crisis, the debate about the need to reform the IMS is only voiced at the most critical moments, being abandoned when the situation appears to have a solution. Thus, at least two other issues, which will not be further developed in this paper, stand out: the limits for cooperation between emerging economies; and the continuity and deepening of existing institutions, with their respective mechanisms of power, as observed with the change of IMF quotas agreed in Seoul (RAMOS et al., 2012).

This impossibility - and even disinterest - of a reform of the post-Second War institutions continues to reproduce a structure of power that does not reflect the current global system, therefore eco- 
nomic approximation between states of the Global South presents itself as an alternative. When the International Monetary System does not provide growth opportunities that states seek, they begin to look for alternatives to liberalization and trade reform (TAYLOR, 2009).

We can conclude that, faced with the impossibility of reforming the International Monetary System, processes of regional economic integration present a viable alternative, mainly - but not only - for developing States. At the same time, some theoretical models on the role of international currencies perceive a tendency to reduce the costs of changing monetary standards through technological advancements, favoring regional and multipolar arrangements, as characteristics such as the proximity of states that issue the currency assume greater importance (EICHENGREEN; LOMBARDI, 2015). Questions remain about the economic and political success of integration, and especially about the different possible levels of implementation. In sum, if the end of Bretton Woods and financial liberalization created an era of uncertainties in terms of the International Monetary System, integration processes have become an alternative in terms of results and economic policy models.

\section{The European Monetary Union}

The European Monetary Union has proven to be an interesting step to European countries since the majority of the trade in the region has always been among its members. According to Baumann (2013), it is possible to recognize four stages in the development of the European Monetary System (EMS) created in 1978: (i) from 1979 to 1983 , with seven realignments between the parities of participating currencies; (ii) from 1983 to 1987 , when four realignments took place; (iii) from 1987 to 1989, with one realignment; and (iv) from 1989 to 1996, with six realignments. The idea of the EMS was to define technical criteria for currency adjustment in case one of them deviated in comparison with the average currencies of the European Community.

The Treaty on European Union (1991), knows as "Treaty of Maastricht" established the European single currency and in January 2000, the Euro started to operate as the official currency of the zone. Although this process of monetary integration is considered to be the most advanced, Baumann (2013) highlights that the path that led to its establishment was full of downsides and frustrated tries with small progresses 5 . The author notes that the whole monetary integration was only possible because of a certain degree of political cohesion between member states (BAUMANN, 2013).

Despite widespread belief that the European Union, particularly the European Monetary Union, would be an experiment to be reproduced in integration experiences worldwide, particularly in Asia and in the Americas, nothing guarantees that its results would be the same, just as the European case itself cannot be considered an absolute success. The creation of the Euro currency reveals a strict social content, based on the Austrian political economy of Carl Menger, a conservative "quasi-gold standard", constraining the freedom of economic and social policies, and imposing "economic laws" on the supposed irrationality of political and democratic processes. A "stateless currency," with neutral fiscal policy and no real monetary authority, but an oligarchy of central banks (represented by the Board of Governors), with monetary stability and zero inflation as an absolute principle without any commitment to employment and growth (PARGUEZ, 2006).

5. For more information on the development of the European Monetary Union, please see Baumann (2013, p. 100-102). 
In contrast, even theoretical models from the Optimum Currency Area were not replicated when developing the European Monetary Union. On the eve of the implementation of the Euro, only France and Luxembourg had fulfilled the convergence criteria established for accession namely, non-deviation from the target exchange rate by more than $2.25 \%$, level of inflation not exceeding $1.5 \%$, interest rate not exceeding $2 \%$ of the average of the three countries with the lowest inflation rate, public deficit of up to $3 \%$ of GDP and total public debt of up to $60 \%$ of the GDP. Furthermore, none of the three conditions for an optimal currency area established by Mundell factor mobility, price flexibility, and regional fiscal transfers - could be ascertained (ARESTIS; SAWYER, 2006).

Moreover, regarding European macroeconomics, monetary policy was adopted as the exclusive instrument of economic policy, with known difficulties arising from its "one policy fits all" nature. Fiscal policy was restricted by deficit targets. The Euro area is unique because it does not have a fiscal authority in addition to the monetary authority, and no coordination between fiscal policy and monetary policy, the latter having the "last word", determining interest rates freely. The Stability and Growth Pact institutionalized a deflationary economic policy stance, calling for tax increases and cuts in spending even in times of recession, to gain credibility vis-à-vis the international financial system, without, however, obtaining any results from its objective. Furthermore, "the broad question is not whether to be 'for' or 'against' the euro per se, but to get the 'right' institutional framework and policy for the achievement of high employment levels throughout the Union” (ARESTIS et. al., 2003, p.1).

\section{Lessons to MERCOSUR and UNASUR: Monetary Cooperation and Regional Arrangements}

In 1991, with the signature of the Asunción Treaty by Argentina, Brazil, Paraguay and Uruguay MERCOSUR was created with the main goal to "to foster a common space that would generate trade and investment opportunities through the competitive integration of national economies into the international market" (MERCOSUR, 2016, $s / p)$. The idea of uniting in a South-South block in order to be more competitive in the international arena was already present.

During the years 2000, MERCOSUR and the Andean Community of Nations (CAN) - an integration experience that dated from the 1960s and whose member states are Bolivia, Colombia, Ecuador, Peru - were passing through a difficult period, when their trade performances started to be questioned. In 2004, aiming at reinforcing those integration experiences, South American Community of Nations (CASA) was created and three years later replaced by UNASUR. The objective was "to be an alternative and a more consistent project of economic integration in South America" (FERRARI-FILHO, 2014, p. 416). All South American countries became member states of UNASUR.

As for the lessons that the history of the European Monetary Union can teach to other integration processes, especially MERCOSUR, one can highlight the importance of a political union for common policies; of an autonomous fiscal policy, not subordinated to monetary policy; and of economic convergence and factor mobility. An attempt to create a monetary union in MERCOSUR would face a series of challenges, namely (i) low unification of markets, far from an optimal monetary area; (ii) low intra-regional trade volume; and 
(iii) lack of economic convergence. All these factors point to the conclusion of a lack of conditions for establishing a monetary union. Moreover, the costs of adoption in MERCOSUR would be higher than they were in the European Union, considering the social problems in the region. To address such problems, compensation mechanisms for fiscal transfers would have to be more flexible, which is difficult in face of fiscal fragility of member states. Therefore, the European Monetary Union model does not seem appropriate for the region. Nonetheless, this question is still premature, as MERCOSUR has not yet reached the stage of a common market, and has problems even for implementing a free trade area, with trade disputes between Brazil and Argentina (ARESTIS et al, 2003).

With more recent data available referring to the period from 2000 to 2010, Ferrari-Filho (2014) and Ferrari-Filho \& Peruffo (2015) observe greater macroeconomic convergence among UNASUR countries in terms of level of growth, unemployment, public deficit and exchange rate regimes. Bearing in mind that this greater convergence could indicate reaching a common market in the future, they propose the creation of an UNASUR SUPRAREGIONAL BOARD, with the objective of institutionalizing a Regional Market Maker capable of stimulating trade and financial relations, disciplining and standardizing macroeconomic policies and avoiding disruptive situations such as financial and currency crises.

Although based on Keynes' ideas about an International Clearing Union, presented in Bretton Woods, Ferrari-Filho (2014) states that there is no need to establish a common currency in UNASUR. Instead, there should be an institutional design to settle rules that allow governments and central banks to expand effective demand in the region. Thus, an UNASUR SUPRAREGIONAL BOARD would work as a Monetary Committee: (i) To coordinate the macroeconomic policies among countries. [...] monetary policy should be employed to control the rate of interest [...] and fiscal policy should be discretionary to support aggregate demand and, by a transfer mechanism, to reduce economic and social differences and integrate among countries' infrastructures;

(ii) To assure that the central banks acts as a lender-of-last-resort [...];

(iii) To implement a common trade policy and distribute the costs of achieving balance of payments equilibrium [...];

(iv) To consolidate the free trade area in the UNASUR, which means to eliminate tariffs, import quotas and preferences on goods and services traded among the UNASUR countries;

(v) To manage an exchange rate regime based on a fixed, but adjustable exchange rate system;

(vi) To promote a system of local currency payments to boost the trade and financial relations among countries (FERRARI-FILHO, 2014, p. 428-429).

More flexible monetary cooperation arrangements, such as the one proposed by Ferrari-Filho (2014) have the advantage of removing all constraints on national fiscal and monetary policies, when compared to monetary integration projects as the European Monetary Union. At the same time, as developed by UNCTAD (2007), they maintain the benefits of protection against international capital markets volatilities, of deepening regional division of labor and of availability of financing under favorable conditions in terms of maturity, interest rates, and currency denomination.

Cooperation in finance and in trade has always had mutual reinforcing trends. Regional payments and clearing agreements help to develop intraregional trade as much as trade integration demands mechanisms for addressing exchange-rate misalignments. There are at least three primary means of monetary cooperation: (1) regional cooperation for payment facilities and short-term financing, which 
includes swap agreements and pooling of reserves among central banks, and the use of domestic currencies in intraregional trade; (2) regional cooperation for development financing, with the creation of regional development banks and regional bond markets; (3) regional exchange-rate coordination mechanisms (UNCTAD, 2007).

Possible benefits from integration, such as negotiation flexibility, depend on the concrete model adopted. In this sense, the analysis of the European Monetary Union shows the great costs that granting autonomy to monetary policy would mean for a monetary union in MERCOSUR and UNASUR. Alternative and less restrictive regimes of monetary cooperation and the development of a multidimensional integration, which besides finance and trade also favors infrastructure, security and military defense sectors, appear to be more likely to succeed. Still, the same problem from European integration holds true: arrangements for coordinating economic and social policy will remain fundamental.

\section{Conclusions}

Despite attempts made by developing countries to change the International Monetary System in a way that it would reflect their current position of greater economic power in the international arena, economic and financial structures remain almost unchanged. The post-financial crisis world, therefore, is also tied to the inertial stance sustained by developed countries. This changes briefly in times of critical economic and financial crises, but faced with small improvement in the situation, developed countries soon return to protecting the status quo. It is also worth noting, on the other hand, that developing countries do not form a homogeneous group, so not all countries of the so-called Global South are interested in a real reform of the IMS.
Faced with the resistance from both developed and developing countries, which prevents deeper restructuring of the IMS, the processes of economic integration are presented as a viable possibility for the states to obtain benefits and for economic growth. The benefits come from the fact that these models of economic integration are shaped through negotiations between states that are interested in being part of the arrangement, guaranteeing greater flexibility. This is in contrast to the IMS, whose structures were established by a restricted group of countries, on which the majority had no voice.

In conclusion, it is also essential to have an adequate analysis of the so-called non-traditional gains from regional integration arrangements, such as security and increased bargaining power, in multilateral negotiations. In this sense, the fact that six South American countries - Argentina, Brazil, Chile, Colombia, Peru and Paraguay - have suspended their membership from UNASUR ten years after the outbreak of the financial crises can be symbolic and paradoxical. Regional blocks have increased developing countries bargaining power in 2008, but in 2018 this model seems to be put aside in order to return to an old model in which the rules are dictated by the Global North. However only in a few years we will be able to assess the consequences and implications of this movement.

\section{References}

Associação Keynesiana Brasileira [AKB]. Desdobramentos da crise financeira internacional, Revista de Economia Política, vol. 31, nº 2 (122), p. 315-335, abr.-jun. 2011.

ARESTIS, P. et al. The Euro and the EMU: Lessons for Mercosur. In: ARESTIS, P.; PAULA, L.F. (eds.). Monetary Union in South America: Lessons from EMU. Cheltenham: Edward Elgar, 2003, pp.14-36.

ARESTIS, P.; SAWYER, M. Reflections on the experience of the euro: lessons for the Americas. In: VERNENGO, M. (ed.). Monetary Integration and Dollarization: no panacea. Cheltenham: Edward Elgar, 2006, p. 13-27. 
BAUMANN, Renato; CANUTO, Otaviano; GONÇALVES, Reinaldo. Economia Internacional: teoria e experiência brasileira. Rio de Janeiro: Elsevier, 2004.

BAUMANN, Renato. Integraçáo Regional: Teoria e Experiencia Latino-Americana. Rio de Janeiro: LTC, 2013.

CARVALHO, Fernando J. Cardim. O G-20 e a Reforma do sistema financeiro: possibilidades e limitaçōes. In: Cintra, M.A.M \& Gomes, Keiti da Rocha (Org.) As transformaçóes no Sistema Financeira Internacional, Volume 1. Brasília: IPEA, 2012.

EICHENGREEN, B.; LOMBARDI, D. RMBI or RMBR: Is the Renminbi Destined to Become a Global or Regional Currency? NBER Working Paper No. 21716, November 2015.

FERRARI-FILHO, Fernando. A regional arrangement proposal for the UNASUR. Revista de Economia Política. V. 34, n.3, p. 413-432, 2014.

FERRARI-FILHO, Fernando; PERUFFO, Luiza. Financial and Monetary Cooperation in South America: Making the Case for a Deeper Integration Among the Unasur Countries, Revista Conjuntura Austral, Porto Alegre, v.6, n. 31, p. 4260, ago./set. 2015.

MERCOSUR. ¿Qué es el MERCOSUR?. Secretaria del MERCOSUR. 2016. Available at: <https://issuu.com/divulgacionmercosur/docs/pocas-palabras_es-web>. Access in 11/9/2017.

PARGUEZ, Alain. The lessons of the European Monetary Union. In: VERNENGO, M. (ed.). Monetary Integration and Dollarization: no panacea. Cheltenham: Edward Elgar, 2006, p. 61-75.

RAMOS, Leonardo; VADELL, Javier; SAGGIORO, Ana \& FERNANDES, Márcia. A Governança econômica global e os desafios do G-20 pós-crise financeira: análise das posições de Estados Unidos, China, Alemanha e Brasil. Rev. bras. polít. int., vol.55, n.2, pp.10-27. 2012

TAYLOR, C. O'Neal. Regionalism: The Second-Best option? Saint Louis University School of Law. Vol. XXVIII:155. 2009. Available at: <http://law.slu.edu/sites/default/files/Journals/ plr28-1_taylor_article.pdf>. Access in 11/9/2017.

UNCTAD. Trade and Development Report. New York/Geneva: United Nations, 2007. 